\title{
Aortic regurgitation with second versus third-generation balloon-expandable prostheses in patients undergoing transcatheter aortic valve implantation
}

David Jochheim ${ }^{1,3}$, MD; Magda Zadroznyํㅜ, MD; Hans Theiss ${ }^{1}$, MD; Moritz Baquet ${ }^{1}$, MD; Fatima Maimer-Rodrigues ${ }^{1}$; Axel Bauer ${ }^{1,3}$, MD; Philipp Lange ${ }^{1}$, MD; Martin Greif ${ }^{1}$, MD;

Christian Kupatt ${ }^{1,3}$, MD; Jörg Hausleiter ${ }^{1,3}$, MD; Christian Hag1 ${ }^{2,3}$, MD; Steffen Massberg ${ }^{1,3}$, MD; Julinda Mehilli ${ }^{1,3 *}$, MD

1. Department of Cardiology, Munich University Clinic, Ludwig-Maximilian University, Munich, Germany; 2. Department of Cardiac Surgery, Munich University Clinic, Ludwig-Maximilian University, Munich, Germany; 3. Munich Heart Alliance at DZHK, Munich, Germany

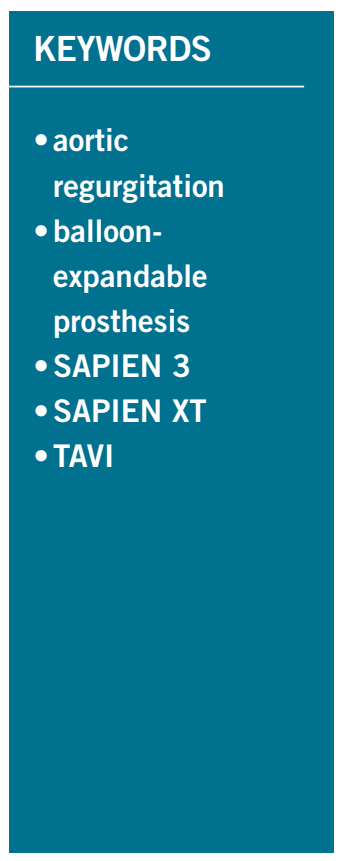

\begin{abstract}
Aims: Our aim was to assess the incidence of aortic regurgitation (AR) after transcatheter aortic valve implantation (TAVI) with the second (SXT) versus third-generation (S3) balloon-expandable SAPIEN prosthesis in patients with symptomatic aortic stenosis (AS).
\end{abstract}

Methods and results: Of 634 patients undergoing TAVI in our centre from May 2010 to July 2014, 354 were treated with the SXT and 100 with the S3 prosthesis. The primary outcome was the incidence of morethan-mild post-TAVI AR at discharge. Secondary outcomes were 30-day incidence of all-cause death, any bleeding complications and need for new pacemaker. The incidence of the primary outcome was $2.0 \%$ vs. $8.8 \%, \mathrm{p}<0.01$ with $\mathrm{S} 3$ compared to SXT, and S3 use was the only independent predictor of post-TAVI AR (odds ratio $0.54 ; 95 \% \mathrm{CI}: 0.33$ to 0.89 ). At 30 days, there were no differences in mortality ( $1.0 \%$ vs. $4.2 \%$, $\mathrm{p}=0.13)$ and pacemaker rate $(12.0 \%$ vs. $10.5 \%, \mathrm{p}=0.59)$ between S3 and SXT. S3-treated patients less frequently had bleeding complications $(24.0 \%$ vs. $41.8 \%, \mathrm{p}<0.01)$ and more often had permanent new left bundle branch block $(22.0 \%$ vs. $7.1 \%, \mathrm{p}<0.001)$.

Conclusions: Compared to the SXT, the use of the S3 prosthesis substantially reduces post-TAVI aortic regurgitation. Longer follow-up is needed to assess if this finding translates to better clinical outcomes.

\footnotetext{
*Corresponding author: Department of Cardiology, Munich University Clinic, Munich Heart Alliance at DZHK, Marchioninistrasse 15,81377 Munich, Germany.E-mail: Julinda.Mehilli@med.uni-muenchen.de
} 


\section{Abbreviations}

AR

aortic regurgitation

LBBB

LVEF

left bundle branch block

LVOT

left ventricular ejection fraction

left ventricular outflow tract

MDCT multi-detector row computed tomography

NYHA New York Heart Association

PCI percutaneous coronary intervention

S3 balloon-expandable SAPIEN 3 prosthesis

SXT balloon-expandable SAPIEN XT prosthesis

TAVI transcatheter aortic valve implantation

VARC-2 Valve Academic Research Consortium-2

\section{Introduction}

With the increasing experience of operators complemented by improvement in prosthetic valve platforms, percutaneous transcatheter aortic valve implantation (TAVI) is becoming a frequently used treatment option not only for patients deemed unsuitable or at high risk for surgical repair but also for elderly patients at intermediate operative risk ${ }^{1,2}$. Nevertheless, with the first and secondgeneration TAVI prostheses, aortic regurgitation (AR) is more frequently observed than after surgical valve repair. The use of balloon-expandable aortic valve prostheses has been proven superior to self-expandable TAVI prostheses in terms of the incidence of device success, post-TAVI AR and the need for new pacemaker implantation ${ }^{3-6}$. Among the aforementioned adverse events, postTAVI more-than-mild AR has been identified as an independent predictor of short and long-term mortality, 5,7 .

The SAPIEN 3 prosthesis (S3; Edwards Lifesciences Inc., Irvine, CA, USA) is the latest revision of the balloon-expandable aortic valve prostheses targeting reduction of post-TAVI paravalvular leak. Different from the second-generation SAPIEN XT prosthesis (SXT), the $\mathrm{S} 3$ consists of a novel steerable balloon system allowing accurate positioning of the valve in the native annulus, a new cobalt-chromium frame with large cell design containing the valve and an outer polyethylene terephthalate cuff to enhance paravalvular sealing. Recent studies including a modest number of patients have demonstrated promising data regarding the acute clinical performance of the $\mathrm{S} 3$, reporting a post-TAVI more-than-mild AR rate of about $2-4 \%{ }^{10}$.

To assess and compare differences in performance between the newer S3 prosthesis and the second-generation SXT prosthesis with regard to post-TAVI AR, we analysed the outcomes of all consecutive patients with symptomatic aortic valve stenosis undergoing transfemoral balloon-expandable prosthesis implantation in our centre.

\section{Material and methods PATIENTS}

Between May 2010 and July 2014, of a total of 634 patients with symptomatic aortic stenosis who underwent transfemoral TAVI procedures at the Munich University Clinic, Munich, Germany, 454 received a balloon-expandable prosthesis and were included in this study. From May 2010 to December 2013, 354 patients underwent SXT implantation (78.0\%), while, from January 2014 to July 2014,
100 patients underwent S3 implantation (22.0\%). Demographics, clinical and procedural data as well as echocardiographic data were prospectively documented in the dedicated database of our institution as part of national quality control requirements. Thirty-day clinical follow-up was available for all patients and was performed either by phone or at the outpatients clinic.

\section{PRE-TAVI ASSESSMENT}

All patients planned for TAVI procedure were assessed by transthoracic echocardiography and in a minority of cases transoesophageal echocardiography. A multi-detector row CT (MDCT) scan was performed in $85 \%$ of the population $(n=388)$ to evaluate the diameter and anatomy of the aortic ring and the aortic valve complex, as well as the vessels for access site, as part of our clinical routine. For patients with severe coronary artery disease, percutaneous coronary intervention was performed prior to TAVI. Evaluation of aortic valve calcification was done semi-quantitatively as previously described $^{3}$. Suitability of patients for TAVI was evaluated within the Heart Team including experienced clinical and interventional cardiologists, cardiovascular surgeons and anaesthesiologists.

\section{DEVICE AND PROCEDURE DESCRIPTION}

Both balloon-expandable prostheses consist of a trileaflet bovine pericardial tissue with a cobalt-chromium support frame. Three commercially available prosthesis sizes $(23 \mathrm{~mm}, 26 \mathrm{~mm}$ and $29 \mathrm{~mm}$ ) were implanted through eSheath systems of $16 \mathrm{Fr}, 18 \mathrm{Fr}$ or $20 \mathrm{Fr}$ for SXT and $14 \mathrm{Fr}$ or $16 \mathrm{Fr}$ for S3 prosthesis. Technical details of both systems and implantation techniques have been previously reported $^{3,8}$. TAVI procedures were mainly performed under local anaesthesia via the transfemoral access. The decision to perform pre- or post-dilation was left to the operator. The decision regarding the prosthesis size was based on the area of the native annulus or the effective diameter in case only echocardiography was available, aiming to achieve an oversize of $10 \%-15 \%$ with SXT prosthesis and $10 \%$ with $\mathrm{S} 3$ prosthesis. Antithrombotic therapy consisted of unfractionated heparin 50-70 IU/kg of body weight or bivalirudin, clopidogrel as a loading dose of 300-600 mg and $75 \mathrm{mg}$ /daily for three months, as well as $100 \mathrm{mg}$ aspirin lifelong. If oral anticoagulation was indicated, it was continued after TAVI as monotherapy.

\section{DEFINITIONS AND OUTCOMES OF INTEREST}

The primary outcome of interest was the incidence of more-thanmild post-TAVI AR determined by echocardiography at hospital discharge. Secondary outcomes of interest were bleeding complications, need for new pacemaker and all-cause mortality at 30-day follow-up. Post-TAVI AR was assessed after procedural implantation at the catheterisation laboratory by using supravalvular angiography after withdrawal of the delivery guidewire from the left ventricle. Aortographies in the $30^{\circ}$ right anterior oblique projection and the $40^{\circ}$ left anterior oblique projection were recorded over several cardiac cycles. The amount of contrast media used ranged between 25-30 ml injected with a flow rate of $15 \mathrm{ml} / \mathrm{sec}$. The severity of post-TAVI AR was assessed visually by two experienced operators 
using the method of Sellers et $\mathrm{al}^{11}$ and classified as: none-trace (0), mild (1/3), moderate (2/3) and severe (3/3). Transthoracic Doppler echocardiography examinations were performed prospectively by two experienced physicians, and in challenging cases a third one repeated the examination and took the final decision. The severity of post-TAVI AR was assessed semi-quantitatively by estimating the proportion of the circumference of the prosthesis covered by the AR jet measured at the short-axis view: less than $10 \%$ was graded as mild, $10 \%$ to $29 \%$ as moderate, and $\geq 30 \%$ as severe paravalvular aortic regurgitation. Device success and other endpoints were defined according to the current VARC-2 consensus ${ }^{12}$.

\section{Statistical analysis}

The population was divided into two groups according to the implanted prosthesis type, S3 and SXT. Continuous data are presented as mean (standard deviation). Categorical data are presented as counts or proportions (\%). Data distribution was tested for normality using the Kolmogorov-Smirnov test for goodness of fit. Differences between groups were checked for significance using the Student's t-test or Wilcoxon rank-sum test (continuous data) or the chi-square or Fisher's exact test where the expected cell value was $<5$ (categorical variables). Odds ratios, confidence intervals and p-values were calculated by means of logistic regression analysis using any post-TAVI AR by echocardiography as dependent variable. Multivariable analysis included risk variables that showed a statistical association with the dependent variable ( $p$-value $\leq 0.10$ ). Missing data in any of the variables considered in the multivariable analysis were neglected. A two-tailed p-value of $<0.05$ was considered to indicate statistical significance. Statistical software R-Statistics (version 3.1.0) was used for analysis.

\section{Results}

\section{BASELINE CHARACTERISTICS AND PROCEDURAL DETAILS}

Detailed information regarding baseline and procedural characteristics is provided in Table 1. No differences were observed between S3 and SXT-treated patients except for the EuroSCORE II, NYHA Class $\geq \mathrm{II}$, incidence of malignancies, mean procedure time and pre/ post-dilation frequency. As shown in Table 2, no differences were observed in baseline echocardiographic and MDCT parameters except for the proportion of patients with reduced LV function, the effective annulus diameter, area cover index, degree of severe aortic cusp calcification and the diameter of the common femoral artery.

\section{PROCEDURAL COMPLICATIONS AND 30-DAY CLINICAL OUTCOMES}

Regarding the peri-TAVI complications, no differences were observed between both groups except a higher incidence of new conduction abnormalities in the S3 group (Table 3).

The incidence of the primary outcome of interest, more-than-mild post-TAVI AR by echocardiography at discharge, was observed less frequently after implantation of the $\mathrm{S} 3$ prosthesis compared to the SXT $(2.0 \%$ vs. $8.8 \%, \mathrm{p}<0.01)$ which was also confirmed by angiography (Figure 1). In the multivariable analysis, an independent
Table 1. Baseline and procedural characteristics.

\begin{tabular}{|c|c|c|c|}
\hline & $\begin{array}{c}\text { SAPIEN } 3 \\
n=100\end{array}$ & $\begin{array}{c}\text { SAPIEN XT } \\
n=354\end{array}$ & $p$-value \\
\hline \multicolumn{4}{|c|}{ Demographics and baseline characteristics } \\
\hline Age, yrs & $79.3 \pm 8.1$ & $80.1 \pm 7.6$ & 0.42 \\
\hline Female & $46(46.0)$ & $200(56.5)$ & 0.11 \\
\hline EuroSCORE II, \% & $5.6 \pm 5.3$ & $8.1 \pm 6.3$ & $<0.001$ \\
\hline Height, cm & $167.7 \pm 9.8$ & $166.5 \pm 9.3$ & 0.21 \\
\hline Weight, kg & $73.6 \pm 13.7$ & $72.8 \pm 15.9$ & 0.27 \\
\hline Body mass index & $26.2 \pm 4.3$ & $26.2 \pm 5.3$ & 0.89 \\
\hline Diabetes & $24(24.0)$ & $97(27.4)$ & 0.09 \\
\hline Hypertension & $84(84.0)$ & $287(81.1)$ & 0.41 \\
\hline NYHA functional class $\geq \|$ & $96(96.0)$ & $280(79.1)$ & $<0.01$ \\
\hline Baseline serum creatinine, $\mathrm{mg} / \mathrm{dl}$ & $1.52 \pm 1.4$ & $1.47 \pm 1.24$ & 0.72 \\
\hline Chronic kidney disease & $33(33.0)$ & $120(33.9)$ & 0.45 \\
\hline on dialysis & $7(7.0)$ & $23(6.5)$ & \\
\hline Coronary artery disease & & & 0.07 \\
\hline without & $41(41.0)$ & $158(44.6)$ & \\
\hline single-vessel & $25(25.0)$ & $51(14.4)$ & \\
\hline two-vessel & $10(10.0)$ & $49(13.8)$ & \\
\hline three-vessel & $24(24.0)$ & 96 (27.2) & \\
\hline History of myocardial infarction & $8(8.0)$ & $41(11.6)$ & 0.35 \\
\hline History of bypass surgery & $9(9.0)$ & $41(11.6)$ & 0.52 \\
\hline History of $\mathrm{PCl}$ & $38(38.0)$ & $118(33.3)$ & 0.29 \\
\hline Malignancies & $4(4.0)$ & $54(15.3)$ & $<0.01$ \\
\hline Atrial fibrillation & $19(19.0)$ & $101(28.5)$ & 0.11 \\
\hline
\end{tabular}

Procedural characteristics

\begin{tabular}{|l|c|c|c|}
\hline TAVI in bioprosthesis & $5(5.0)$ & $18(5.1)$ & 0.98 \\
\hline Predilation performed & $85(85.0)$ & $344(97.2)$ & $<0.001$ \\
\hline Prosthesis size & & & 0.01 \\
\hline $23 \mathrm{~mm}$ & $43(43.0)$ & $97(27.4)$ & \\
\hline $26 \mathrm{~mm}$ & $39(39.0)$ & $189(53.4)$ & \\
\hline $29 \mathrm{~mm}$ & $18(18.0)$ & $68(19.2)$ & \\
\hline Post-dilation performed & $9(9.0)$ & $111(31.4)$ & $<0.001$ \\
\hline Depth of implantation, mm & $6.9 \pm 2.0$ & $6.6 \pm 2.2$ & 0.23 \\
\hline Procedure time, minutes & $53.3 \pm 20.5$ & $102.5 \pm 47.0$ & $<0.001$ \\
\hline
\end{tabular}

Values are mean $\pm S D$ or $n(\%)$. EuroSCORE: European System for Cardiac Operative Risk Evaluation; NYHA: New York Heart Association; PCl: percutaneous coronary intervention

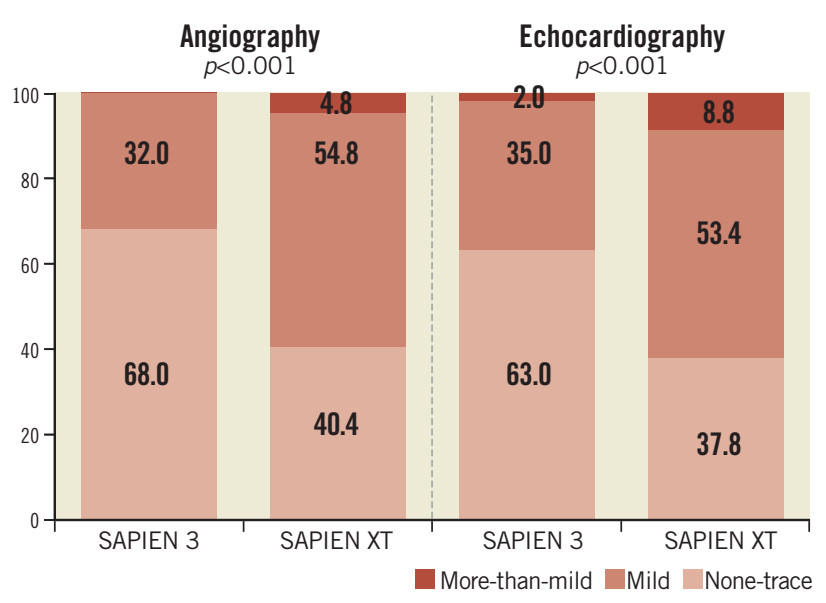

Figure 1. Incidence of aortic regurgitation after TAVI. 
Table 2. Baseline echocardiographic and multidetector computed tomography measurements.

\begin{tabular}{|c|c|c|c|}
\hline & $\begin{array}{c}\text { SAPIEN } 3 \\
n=100\end{array}$ & $\begin{array}{c}\text { SAPIEN XT } \\
n=354\end{array}$ & $p$-value \\
\hline \multicolumn{4}{|l|}{ Echocardiography } \\
\hline Aortic valve area, $\mathrm{cm}^{2}$ & $0.7 \pm 0.1$ & $0.7 \pm 0.2$ & 0.45 \\
\hline Mean gradient, $\mathrm{mmHg}$ & $39.2 \pm 13.7$ & $40.4 \pm 15.5$ & 0.56 \\
\hline Left ventricular ejection fraction $<50 \%$ & $43(43.0)$ & $112(21.6)$ & $<0.001$ \\
\hline Severe aortic insufficiency & $20(20.0)$ & $49(13.8)$ & 0.14 \\
\hline Severe mitral insufficiency & $3(3.0)$ & $14(4.0)$ & 0.51 \\
\hline \multicolumn{4}{|c|}{ Multidetector computed tomography* } \\
\hline Effective annulus diameter ${ }^{\diamond}, \mathrm{mm}$ & $24.2 \pm 2.5$ & $23.4 \pm 3.8$ & 0.02 \\
\hline Annulus area, $\mathrm{cm}^{2}$ & $4.59 \pm 0.86$ & $4.50 \pm 0.94$ & 0.43 \\
\hline Annulus perimeter, $\mathrm{mm}$ & $74.5 \pm 17.2$ & $73.2 \pm 17.6$ & 0.54 \\
\hline Area cover index, \% & $9.1 \pm 9.1$ & $14.8 \pm 11.1$ & $<0.01$ \\
\hline Annulus eccentricity", \% & $23.0 \pm 9.0$ & $23.0 \pm 8.0$ & 0.89 \\
\hline Degree of aortic cusp calcification & & & 0.03 \\
\hline Mild & $4(4.0)$ & $31(10.7)$ & \\
\hline Moderate & $28(28.0)$ & $89(33.9)$ & \\
\hline Severe & $59(59.0)$ & $128(44.1)$ & \\
\hline Degree of annulus calcification & & & 0.52 \\
\hline Mild & $33(33.0)$ & 96 (33.3) & \\
\hline Moderate & $11(11.0)$ & $39(13.6)$ & \\
\hline Severe & $2(2.0)$ & $16(5.6)$ & \\
\hline Degree of LVOT calcification & & & 0.24 \\
\hline Mild & $14(14.0)$ & 33 (11.3) & \\
\hline Moderate & $2(2.0)$ & $10(3.4)$ & \\
\hline Severe & 0 & $5(1.7)$ & \\
\hline Left coronary artery height, $\mathrm{mm}$ & $12.8 \pm 2.4$ & $12.9 \pm 3.0$ & 0.84 \\
\hline Right coronary artery height, mm & $14.6 \pm 3.4$ & $13.6 \pm 3.4$ & 0.02 \\
\hline FCA diameter at access site, $\mathrm{mm}$ & $8.4 \pm 1.8$ & $9.2 \pm 5.8$ & 0.03 \\
\hline \multicolumn{4}{|c|}{ 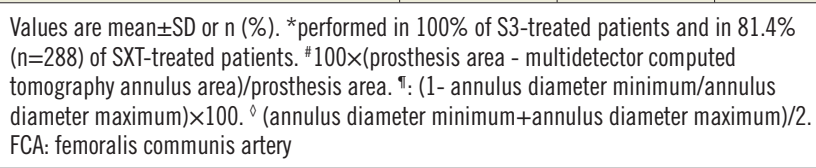 } \\
\hline
\end{tabular}

predictor of post-TAVI AR was the type of implanted prosthesis, with S3 being a protective factor (Figure 2, Table 4). Furthermore, we analysed the incidence and severity of post-TAVI AR in subgroups with 50 patients each to evaluate the possible impact of the operators' learning curve on this event. After the first 100 SXT implantation procedures, the rate of more-than-mild AR was reduced; however, it still remained higher compared to the incidence of AR post S3 implantation (Figure 3).

Thirty-day follow-up was available for all patients. In total, 16 patients died $(3.5 \%)$, without significant difference in both groups $(\mathrm{p}=0.13)$. Compared to the SXT-treated group, in the $\mathrm{S} 3$-treated group the rate of bleeding complications was significantly lower, while the need for new pacemaker and the proportion of patients with new left bundle branch block at discharge were significantly higher (Table 3).

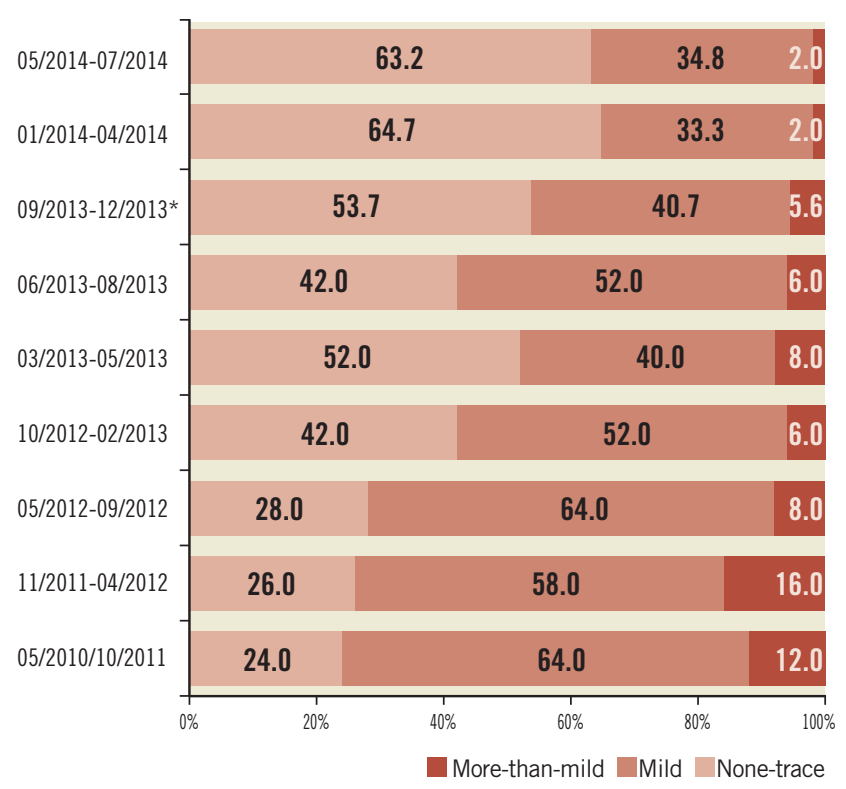

Figure 3. Incidence of aortic regurgitation after TAVI in different subgroups. * the only subgroup with 54 patients, all other subgroups have 50 patients each.

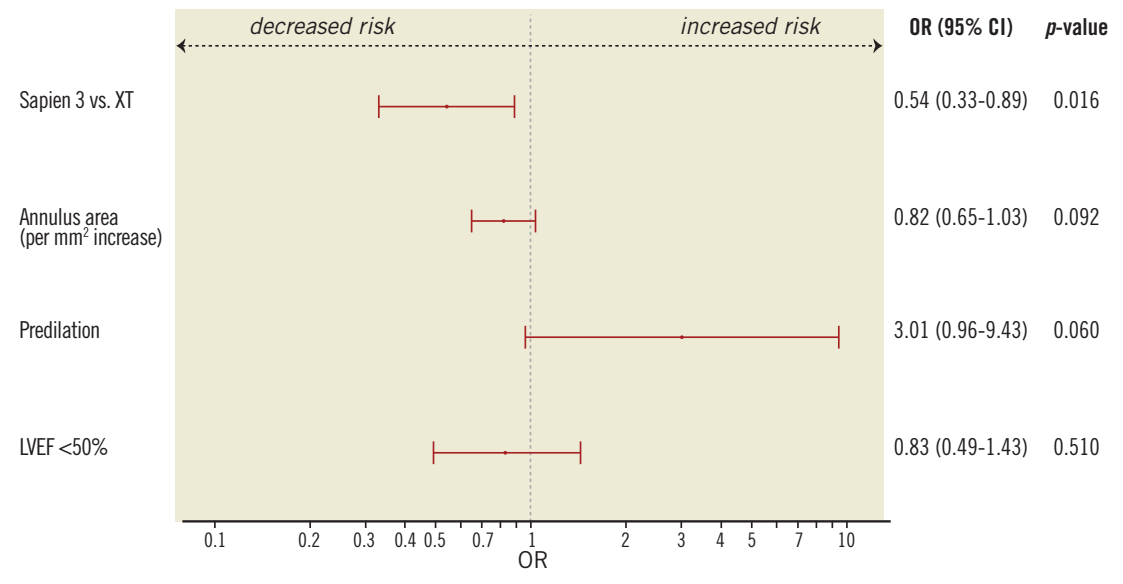

Figure 2. Independent predictors of post-TAVI aortic regurgitation. CI: confidence interval; LVEF: left ventricular ejection fraction; OR: odds ratio 
Table 3. Periprocedural complications and clinical outcomes at 30-day follow-up.

\begin{tabular}{|l|c|c|c|}
\hline & $\begin{array}{c}\text { SAPIEN 3 } \\
\mathbf{n}=100\end{array}$ & $\begin{array}{c}\text { SAPIEN XT } \\
\mathbf{n}=354\end{array}$ & $\boldsymbol{p}$-value \\
\hline \multicolumn{3}{|l|}{ Periprocedural complications } \\
\hline Implantation of $\geq 2$ valves & 0 & $4(1.1)$ & - \\
\hline New conduction disturbances & & & $<0.001$ \\
\hline \multicolumn{1}{|c|}{ LBBB } & $31(31.0)$ & $47(13.3)$ & \\
\hline \multicolumn{1}{|c|}{ AV block II-III } & & \\
\hline Coronary obstruction & $3(3.0)$ & $18(5.1)$ & \\
\hline Conversion to open surgery & 0 & $3(0.8)$ & - \\
\hline Cardiopulmonary resuscitation & 0 & $1(0.3)$ & - \\
\hline Annulus rupture & $2(2.0)$ & $13(3.7)$ & 0.43 \\
\hline Pericardial tamponade & $1(1.0)$ & $4(1.1)$ & 0.85 \\
\hline Device success & $1(1.0)$ & $5(1.4)$ & 0.77 \\
\hline
\end{tabular}

Echocardiography at discharge

\begin{tabular}{|l|c|c|c|}
\hline Prosthesis mean gradient, $\mathrm{mmHg}$ & $11.8 \pm 4.2$ & $11.2 \pm 3.64$ & 0.21 \\
\hline Transvalvular prosthesis leak & $2(2.0)$ & $12(3.4)$ & 0.74 \\
\hline Paravalvular prosthesis leak & $35(35.0)$ & $208(58.8)$ & $<0.001$ \\
\hline Regurgitant jet >1* & $2(5.4)$ & $6(2.9)$ & 0.24 \\
\hline Location of paravalvular jets & & & 0.90 \\
\hline \multicolumn{1}{|c|}{ A coronary sinus } & $11(31.4)$ & $53(25.5)$ & \\
\hline \multicolumn{1}{|c|}{ Left coronary sinus } & $12(34.3)$ & $67(32.2)$ & \\
\hline \multicolumn{1}{|c|}{ Right coronary sinus } & $12(34.3)$ & $88(42.3)$ & \\
\hline
\end{tabular}

30-day clinical outcomes according to VARC-2 criteria

\begin{tabular}{|l|c|c|c|}
\hline All-cause death & $1(1.0)$ & $15(4.2)$ & 0.13 \\
\hline Any bleeding & $24(24.0)$ & $148(41.8)$ & 0.001 \\
\hline Major or life-threatening bleeding & $10(10.0)$ & $59(16.7)$ & 0.10 \\
\hline Minor bleeding & $14(14.0)$ & $89(25.1)$ & 0.02 \\
\hline Vascular complications & & & 0.87 \\
\hline \multicolumn{1}{|c|}{ Minor } & $11(11.0)$ & $45(12.7)$ & \\
\hline \multicolumn{1}{|c|}{ Major } & $7(7.0)$ & $29(8.2)$ & \\
\hline Acute kidney injury & $10(10.0)$ & $25(7.1)$ & 0.53 \\
\hline Major stroke & $2(2.0)$ & $6(1.7)$ & 0.80 \\
\hline Permanent new LBBB & $22(22.0)$ & $25(7.1)$ & $<0.001$ \\
\hline New pacemaker & $12(12.0)$ & $37(10.5)$ & 0.59 \\
\hline
\end{tabular}

Values are mean $\pm S D$ or $n(\%)$. *based on number of patients with AR. " based on number of patients with paravalvular leak. AV: atrioventricular node; LBBB: left bundle branch block; VARC-2: Valve Academic Research Consortium-2

\section{Discussion}

Our study is the largest single-centre experience with second and third-generation balloon-expandable prostheses in patients undergoing TAVI. The main findings of this analysis are: i) the use of the third-generation balloon-expandable S3 prosthesis is associated with a substantially lower incidence of both any and morethan-mild post-TAVI AR compared to the second-generation SXT prosthesis; ii) the type of prosthesis implanted is identified as the only independent predictor of post-TAVI AR; iii) compared to the
Table 4. Univariable and multivariable predictors of any post-TAVI AR.

\begin{tabular}{|c|c|c|c|c|}
\hline \multirow{2}{*}{ Risk predictors } & \multicolumn{2}{|c|}{ Univariable } & \multicolumn{2}{|c|}{ Multivariable } \\
\hline & OR (95\% CI) & $p$-value & OR (95\% CI) & $p$-value \\
\hline Gender & $1.35(0.94-1.96)$ & 0.11 & & \\
\hline NYHA Class $\geq \| l$ & $1.46(0.87-2.46)$ & 0.16 & & \\
\hline LVEF $<50 \%$ & $0.58(0.36-0.94)$ & 0.03 & $0.83(0.49-1.43)$ & 0.51 \\
\hline Predilation & $4.61(1.54-13.76)$ & $<0.01$ & $3.01(0.96-9.43)$ & 0.06 \\
\hline Aortic cusp calcification & $0.98(0.46-2.09)$ & 0.95 & & \\
\hline $\begin{array}{l}\text { Aortic annulus effective } \\
\text { diameter }\end{array}$ & $0.98(0.92-1.03)$ & 0.42 & & \\
\hline Aortic annulus area & $0.79(0.63-0.99)$ & 0.04 & $0.82(0.65-1.03)$ & 0.09 \\
\hline Area cover index & $0.98(0.96-1.00)$ & 0.05 & & \\
\hline S3 prosthesis implantation & $0.48(0.30-0.77)$ & $<0.01$ & $0.54(0.33-0.89)$ & 0.02 \\
\hline
\end{tabular}

SXT prosthesis, clinical outcomes, particularly bleeding risk, are improved after implantation of the S3 prosthesis while the incidence of new conduction disturbances is increased.

Post-TAVI AR remains a major limitation of earlier-generation TAVI prostheses and is mainly provoked by several causes related to valve positioning and sizing ${ }^{5,13}$, annular anatomy, including presence and distribution of calcium ${ }^{14,15}$, and notably the type of prosthesis ${ }^{3,5}$. The incidence of more-than-mild post-TAVI AR after SXT implantation in our study was $8.8 \%$, which is within the reported range of $3 \%$ to $13 \%$ in the current literature ${ }^{3,5,7}$. In addition, the observed rate of any post-TAVI AR of $60 \%$ is also within the range of $40 \%-70 \%$ reported with the SXT prosthesis in other studies ${ }^{3,6,10}$. The third generation of balloon-expandable $\mathrm{S} 3$ prosthesis is designed to target post-TAVI paravalvular leak. Recent studies including a modest number of patients have demonstrated promising data regarding acute clinical performance of S3, reporting, similar to our series (2\%), a post-TAVI more-thanmild AR rate up to $4 \%{ }^{10}$. Post-TAVI AR mostly originates from incomplete apposition of the aortic valve frame against the native wall $^{16}$. While undersizing can lead to severe paravalvular AR, excessive oversizing may induce annulus rupture ${ }^{13,17}$. Our data show that improvement in S3 prosthesis design allows for less oversize to achieve less post-TAVI AR compared to SXT (9\% vs. $14.8 \%$ ). Another important factor that might improve prosthesis haemodynamics is balloon post-dilatation. The rationale to perform post-dilation is either the incomplete delivery of pressure to the balloon or the incomplete expansion of the valve prosthesis due to intense resistance of the aortic wall ${ }^{18}$. Post-dilatation in some cases reduces post-TAVI AR, but on the other hand it also increases the risk of neurological events and aortic trauma ${ }^{17,18}$. The need for post-dilation is substantially reduced after implantation of the $\mathrm{S} 3{ }^{10}$ (9\% vs. $31 \%$ in the SXT group) which is partially contributed to by the substantial reduction of procedural time with the $\mathrm{S} 3$ prosthesis.

Aortic valve calcification is essential to anchor and achieve appropriate positioning of a balloon-expandable TAVI prosthesis. 
On the other hand, severe and asymmetric distribution of calcium masses has been associated with post-TAVI paravalvular $\mathrm{AR}^{14,19}$. In our study, a severe degree of aortic valve calcification did not predict the risk of post-TAVI AR.

More-than-mild AR after implantation of earlier generations of balloon-expandable prostheses has been associated with increased mortality ${ }^{9,20,21}$. Similar to other studies, 30-day mortality among SXT-treated patients in our study was $4.2 \%$, which is numerically higher than the mortality among S3-treated patients $(1.0 \%$, $\mathrm{p}=0.13$ ). Caution is required in interpreting these findings. First, the number of S3-treated patients is still modest for evaluating mortality. Second, compared to SXT-treated patients, S3-treated patients presented with a lower EuroSCORE II - which might reflect changes in indication for TAVI in time - and also significantly less frequently experienced bleeding complications which might have positively influenced survival after TAVI. Third, a greater impact of the operators' learning curve on the outcomes of the SXT prosthesis (S3 was used after 3.5 years of experience with SXT) cannot be ruled out.

A novel observation of our study is the twofold increase in the rate of new conduction disturbances with the $\mathrm{S} 3$ prosthesis compared to the SXT prosthesis, although similar rates of new pacemaker implantation were observed. Assessment of factors determining this complication is beyond the scope of this paper. However, it can be speculated that the higher proportion of severely calcified aortic valves among S3-treated patients as well as the S3 novel frame with larger angles between struts and interwoven rows of cells designed for high radial strength to achieve optimal circularity might increase the rate of conduction disturbances. The higher pacemaker rate reported after implantation of other novel prostheses with higher radial strength, such as the Lotus ${ }^{\mathrm{TM}}$ (Boston Scientific, Marlborough, MA, USA), supports this hypothesis ${ }^{22}$. Despite this, our findings strongly suggest reduction of limiting and life-threatening complications of TAVI procedures with the new S3 prosthesis.

\section{Limitations}

First, the present study is a non-randomised comparison of two different generations of balloon-expandable prostheses. Second, although the reduction of post-TAVI AR with the S3 evaluated by echocardiography was confirmed angiographically, a central echocardiographic core laboratory evaluation was not performed. Furthermore, the sample size is enough for the kind of analysis performed but insufficient to unveil rare complications and clinical outcomes.

\section{Conclusions}

In patients undergoing transfemoral aortic valve implantation, the third-generation balloon-expandable S3 prosthesis substantially reduces post-TAVI aortic regurgitation compared to the second-generation SXT. Its use independently predicts lower post-TAVI AR risk and is associated with better clinical outcomes.

\section{Impact on daily practice}

Aortic regurgitation after transcatheter aortic valve implantation (TAVI) has been shown to increase long-term mortality. Therefore, improvements in prosthesis design are targeted towards this complication. In our study, compared to the earliergeneration balloon-expandable SAPIEN XT prosthesis, the use of the new revision SAPIEN 3 is associated with a significant reduction of post-TAVI aortic regurgitation, which is independent of other known risk factors. Furthermore, periprocedural and 30-day clinical outcomes seem to be better with the S3 compared to the SXT prosthesis, suggesting a better overall performance of the new $\mathrm{S} 3$ prosthesis in everyday practice.

\section{Funding}

The registry was funded by the Munich Heart Alliance partner site of DZHK.

\section{Conflict of interest statement}

J. Mehilli, J. Hausleiter and C. Kupatt have received modest lecture fees from Edwards Lifesciences. The other authors have no conflicts of interest to declare.

\section{References}

1. Leon MB, Smith CR, Mack M, Miller DC, Moses JW, Svensson LG, Tuzcu EM, Webb JG, Fontana GP, Makkar RR, Brown DL, Block PC, Guyton RA, Pichard AD, Bavaria JE, Herrmann HC, Douglas PS, Petersen JL, Akin JJ, Anderson WN, Wang D, Pocock S; PARTNER Trial Investigators. Transcatheter aortic-valve implantation for aortic stenosis in patients who cannot undergo surgery. N Engl J Med. 2010;363:1597-607.

2. Adams DH, Popma JJ, Reardon MJ, Yakubov SJ, Coselli JS, Deeb GM, Gleason TG, Buchbinder M, Hermiller J Jr, Kleiman NS, Chetcuti S, Heiser J, Merhi W, Zorn G, Tadros P, Robinson N, Petrossian G, Hughes GC, Harrison JK, Conte J, Maini B, Mumtaz M, Chenoweth S, Oh JK; U.S. CoreValve Clinical Investigators. Transcatheter aortic-valve replacement with a self-expanding prosthesis. N Engl J Med. 2014;370:1790-8.

3. Abdel-Wahab M, Mehilli J, Frerker C, Neumann FJ, Kurz T, Tolg R, Zachow D, Guerra E, Massberg S, Schafer U, El-Mawardy M, Richardt G; CHOICE investigators. Comparison of balloon-expandable vs self-expandable valves in patients undergoing transcatheter aortic valve replacement: the CHOICE randomized clinical trial. JAMA. 2014;311:1503-14.

4. Urena M, Webb JG, Tamburino C, Munoz-Garcia AJ, Cheema A, Dager AE, Serra V, Amat-Santos IJ, Barbanti M, Imme S, Briales JH, Benitez LM, Al Lawati H, Cucalon AM, Garcia Del Blanco B, Lopez J, Dumont E, Delarochelliere R, Ribeiro HB, Nombela-Franco L, Philippon F, Rodes-Cabau J. Permanent pacemaker implantation after transcatheter aortic valve implantation: impact on late clinical outcomes and left ventricular function. Circulation. 2014;129:1233-43.

5. Van Belle E, Juthier F, Susen S, Vincentelli A, Iung B, Dallongeville J, Eltchaninoff H, Laskar M, Leprince P, Lievre M, 
Banfi C, Auffray JL, Delhaye C, Donzeau-Gouge P, Chevreul K, Fajadet J, Leguerrier A, Prat A, Gilard M, Teiger E; FRANCE 2 Investigators. Postprocedural aortic regurgitation in balloon-expandable and self-expandable transcatheter aortic valve replacement procedures: analysis of predictors and impact on long-term mortality: insights from the FRANCE2 Registry. Circulation. 2014;129:1415-27.

6. Gilard $\mathrm{M}$, Eltchaninoff $\mathrm{H}$, Iung $\mathrm{B}$, Donzeau-Gouge $\mathrm{P}$, Chevreul K, Fajadet J, Leprince P, Leguerrier A, Lievre M, Prat A, Teiger E, Lefevre T, Himbert D, Tchetche D, Carrie D, Albat B, Cribier A, Rioufol G, Sudre A, Blanchard D, Collet F, Dos Santos P, Meneveau N, Tirouvanziam A, Caussin C, Guyon P, Boschat J, Le Breton H, Collart F, Houel R, Delpine S, Souteyrand G, Favereau X, Ohlmann P, Doisy V, Grollier G, Gommeaux A, Claudel JP, Bourlon F, Bertrand B, Van Belle E, Laskar M; FRANCE 2 Investigators. Registry of transcatheter aortic-valve implantation in high-risk patients. N Engl J Med. 2012;366:1705-15.

7. Athappan G, Patvardhan E, Tuzcu EM, Svensson LG, Lemos PA, Fraccaro C, Tarantini G, Sinning JM, Nickenig G, Capodanno D, Tamburino C, Latib A, Colombo A, Kapadia SR. Incidence, predictors, and outcomes of aortic regurgitation after transcatheter aortic valve replacement: meta-analysis and systematic review of literature. J Am Coll Cardiol. 2013;61:1585-95.

8. Binder RK, Rodes-Cabau J, Wood DA, Mok M, Leipsic J, De Larochelliere R, Toggweiler S, Dumont E, Freeman M, Willson AB, Webb JG. Transcatheter aortic valve replacement with the SAPIEN 3: a new balloon-expandable transcatheter heart valve. JACC Cardiovasc Interv. 2013;6:293-300.

9. Kodali SK, Williams MR, Smith CR, Svensson LG, Webb JG, Makkar RR, Fontana GP, Dewey TM, Thourani VH, Pichard AD, Fischbein M, Szeto WY, Lim S, Greason KL, Teirstein PS, Malaisrie SC, Douglas PS, Hahn RT, Whisenant B, Zajarias A, Wang D, Akin JJ, Anderson WN, Leon MB; PARTNER Trial Investigators. Two-year outcomes after transcatheter or surgical aortic-valve replacement. N Engl J Med. 2012;366:1686-95.

10. Amat-Santos IJ, Dahou A, Webb J, Dvir D, Dumesnil JG, Allende R, Ribeiro HB, Urena M, Paradis JM, DeLarochelliere R, Dumont E, Bergeron S, Thompson CR, Pasian S, Bilodeau S, Leipsic J, Larose E, Pibarot P, Rodes-Cabau J. Comparison of hemodynamic performance of the balloon-expandable SAPIEN 3 versus SAPIEN XT transcatheter valve. Am J Cardiol. 2014;114:1075-82.

11. Sellers RD, Levy MJ, Amplatz K, Lillehei CW. Left Retrograde Cardioangiography in Acquired Cardiac Disease: Technic, Indications and Interpretations in 700 Cases. Am J Cardiol. 1964;14:437-47.

12. Kappetein AP, Head SJ, Genereux P, Piazza N, van Mieghem NM, Blackstone EH, Brott TG, Cohen DJ, Cutlip DE, van Es GA, Hahn RT, Kirtane AJ, Krucoff MW, Kodali S, Mack MJ, Mehran R, Rodes-Cabau J, Vranckx P, Webb JG, Windecker S, Serruys PW, Leon MB. Updated standardized endpoint definitions for transcatheter aortic valve implantation: the Valve Academic Research Consortium-2 consensus document. Eur Heart J. 2012;33:2403-18.

13. Detaint D, Lepage L, Himbert D, Brochet E, MessikaZeitoun D, Iung B, Vahanian A. Determinants of significant paravalvular regurgitation after transcatheter aortic valve: implantation impact of device and annulus discongruence. JACC Cardiovasc Interv. 2009;2:821-7.

14. Khalique OK, Hahn RT, Gada H, Nazif TM, Vahl TP, George I, Kalesan B, Forster M, Williams MB, Leon MB, Einstein AJ, Pulerwitz TC, Pearson GD, Kodali SK. Quantity and location of aortic valve complex calcification predicts severity and location of paravalvular regurgitation and frequency of post-dilation after balloon-expandable transcatheter aortic valve replacement. JACC Cardiovasc Interv. 2014;7:885-94.

15. Clavel MA, Pibarot P, Messika-Zeitoun D, Capoulade R, Malouf J, Aggarval S, Araoz PA, Michelena HI, Cueff C, Larose E, Miller JD, Vahanian A, Enriquez-Sarano M. Impact of aortic valve calcification, as measured by MDCT, on survival in patients with aortic stenosis: results of an international registry study. J Am Coll Cardiol. 2014;64:1202-13.

16. Piazza N, de Jaegere P, Schultz C, Becker AE, Serruys PW, Anderson RH. Anatomy of the aortic valvar complex and its implications for transcatheter implantation of the aortic valve. Circ Cardiovasc Interv. 2008;1:74-81.

17. Barbanti M, Yang TH, Rodes Cabau J, Tamburino C, Wood DA, Jilaihawi H, Blanke P, Makkar RR, Latib A, Colombo A, Tarantini G, Raju R, Binder RK, Nguyen G, Freeman M, Ribeiro HB, Kapadia S, Min J, Feuchtner G, Gurtvich R, Alqoofi F, Pelletier M, Ussia GP, Napodano M, de Brito FS Jr, Kodali S, Norgaard BL, Hansson NC, Pache G, Canovas SJ, Zhang H, Leon MB, Webb JG, Leipsic J. Anatomical and procedural features associated with aortic root rupture during balloon-expandable transcatheter aortic valve replacement. Circulation. 2013;128:244-53.

19. Hahn RT, Pibarot P, Webb J, Rodes-Cabau J, Herrmann HC, Williams M, Makkar R, Szeto WY, Main ML, Thourani VH, Tuzcu EM, Kapadia S, Akin J, McAndrew T, Xu K, Leon MB, Kodali SK. Outcomes with post-dilation following transcatheter aortic valve replacement: the PARTNER I trial (placement of aortic transcatheter valve). JACC Cardiovasc Interv. 2014;7:781-9.

19. Unbehaun A, Pasic M, Dreysse S, Drews T, Kukucka M, Mladenow A, Ivanitskaja-Kuhn E, Hetzer R, Buz S. Transapical aortic valve implantation: incidence and predictors of paravalvular leakage and transvalvular regurgitation in a series of 358 patients. $\mathrm{J} \mathrm{Am}$ Coll Cardiol. 2012;59:211-21.

20. Toggweiler S, Humphries KH, Lee M, Binder RK, Moss RR, Freeman M, Ye J, Cheung A, Wood DA, Webb JG. 5-year outcome after transcatheter aortic valve implantation. $\mathrm{J} \mathrm{Am} \mathrm{Coll} \mathrm{Cardiol.}$ 2013;61:413-9.

21. Genereux P, Head SJ, Hahn R, Daneault B, Kodali S, Williams MR, van Mieghem NM, Alu MC, Serruys PW, Kappetein AP, Leon MB. Paravalvular leak after transcatheter aortic valve replacement: the new Achilles' heel? A comprehensive review of the literature. J Am Coll Cardiol. 2013;61:1125-36.

22. Meredith IT, Worthley SG, Whitbourn RJ, Antonis P, Montarello JK, Newcomb AE, Lockwood S, Haratani N, Allocco DJ, Dawkins KD. Transfemoral aortic valve replacement with the repositionable Lotus Valve System in high surgical risk patients: the REPRISE I study. EuroIntervention. 2014;9: 1264-70. 